\title{
Experiencing the Real Presence of Christ in the Eucharist
}

\author{
Joshua Cockayne \\ David Efird \\ Gordon Haynes \\ Daniel Molto \\ Richard Tamburro \\ Jack Warman \\ University of York
}

August Ludwigs

University of Oxford

\begin{abstract}
We present a new understanding of Christ's real presence in the Eucharist on the model of Stump's account of God's omnipresence and Green and Quan's account of experiencing God in Scripture. On this understanding, Christ is derivatively, rather than fundamentally, located in the consecrated bread and wine, such that Christ is present to the believer through the consecrated bread and wine, thereby making available to the believer a second-person experience of Christ, where the consecrated bread and wine are the way in which she shares attention with him. The consecrated bread and wine are then, in a sense, icons of Christ.
\end{abstract}

He wondered where she had hidden herself, ... [t] he woman who knelt down on the floor in front of him, and took him by the shoulders on the morning of his First Holy Communion, and said, 'Remember who you are. When you take the host, say it in your heart: Hello Jesus, my name is Emmet Madigan.'

Anne Enright, The Green Road

'And remember, I am with you always, to the end of the age' (Matthew 28.20; all biblical references are to the NRSV). So ends the Gospel according to Matthew, with Christ's last words to his disciples. Now, many present Christians, latter day disciples, as it were, take these last words of Christ to apply not only to the disciples of the early

Journal of Analytic Theology, Vol. 5, May 2017

10.12978/jat.2017-5.091400021404a

(C) 2017 Joshua Cockayne, David Efird, Gordon Haynes, August Ludwigs, Daniel Molto, Richard Tamburro, Jack Warman • (C) 2017 Journal of Analytic Theology 
first century but also to them. But, given that we, and indeed the disciples of the early first century, following Christ's ascension, do not see Christ as the disciples saw him in his earthly life, as a physical person whom we can see, hear, and touch, how is it possible for Christ to be with them and us always? No question could be more urgent for those who, like the disciples of the early first century, wish to live in relationship with him, though they have never seen, heard, or touched him as a physical person.

One way to give a philosophical explanation of Christ's presence with us now, even though we do no not see him as the disciples then saw him, is to point to Christ's 'real presence' in the Eucharist, and then try to explain just what 'real presence' amounts to. The Eucharist is a sacrament of the Church that signifies not only grace in those who participate in it but also the 'real presence' of Christ in the sacrament itself. In this sacrament, the Church re-enacts Christ's last supper with his disciples: in the liturgy of the sacrament, a priest takes bread and repeats Christ's words, 'This is my body which is given for you. Do this in remembrance of me', and then takes a cup of wine and, again, repeats Christ's words, 'This is the cup of the new covenant in my blood. Do this, as often as you drink it, in remembrance of me', and, after invoking the Holy Spirit, Christ is now 'really present' in the Eucharist in virtue of standing in some sort of relation to the consecrated bread and wine.

Just what this relation is has puzzled philosophical theologians for centuries, with answers tending to fall into two groupings: either identity, where the consecrated bread and wine is, in some way, Christ himself, or symbolic, where the consecrated bread and wine, in some way, symbolize Christ. In this paper, we present a new way of understanding this relation, namely, iconic, where the consecrated bread and wine serve as icons of Christ. ${ }^{1}$ On this understanding, the consecrated bread and wine are ways of, and occasions for, a second-person experience of Christ, whereby the communicant shares attention with Christ. We motivate this account by considering some recent advances in the debate on God's omnipresence, itself a puzzling doctrine, using the lessons learned to chart the way forward in the debate on Christ's real presence in the Eucharist.

\section{God's omnipresence and Christ's 'real presence' in the Eucharist}

With respect to every place, God is present there, or so says the doctrine of omnipresence. And if presence implies location, as it seems to do, then, with respect

\footnotetext{
${ }^{1}$ Although this is a new position, there are similarities with our account and a Lutheran understanding of Christ's true presence in the Eucharist. According to Luther, Christ is present in the elements since, by his divine nature, he is present at all places. However, he is present in a particular way in Eucharist, since he is present to the individual. This Lutheran model is also adopted by Søren Kierkegaard (2011). Although we too emphasise Christ's presence to the participant, we circumvent the issues which Luther raises concerning Christ's ubiquity, since commitment to this doctrine isn't necessary for the position we develop.
} 
to every place, God is located there. Now, according to Ross Inman, there are two ways for an object $x$ to be located at a place $p$ :

Fundamental Location: $x$ is located at $p$ fundamentally $=_{\mathrm{df}} x$ is located at $p$ in its own right, i.e. not in virtue of standing in a relation(s), to some distinct $y$ that is located at $p$ in its own right.

Derivative Location: $x$ is located at $p$ derivatively $=_{\mathrm{df}} x$ is located at $p$ in virtue of standing in some relation(s), to some distinct entity, $y$, where $y$ is located at $p$ fundamentally. (Inman forthcoming, 3)

Both approaches have their recent champions. Hud Hudson (2009, 2014), Inman (forthcoming), Robert Oakes, (2006) and Alexander Pruss (2013) defend fundamental location accounts of God's omnipresence, while William Lane Craig and J.P. Moreland (2003), Joshua Hoffman and Gary S. Rosenkranz (2002), Eleonore Stump (2010, 2013), Richard Swinburne (1993), Charles Taliaferro (1994), and Edward Wierenga (2010) defend derivative location accounts of God's omnipresence.

We can understand the debate about the real presence of Christ in the Eucharist in similar terms. One way for Christ to be really present in the Eucharist is for him to be present in the consecrated bread and wine, and so be located in the consecrated bread and wine, and so be located at the place occupied by the consecrated bread and wine. This would then be a fundamental location account of the real presence of Christ in the Eucharist. The most prominent such account is the doctrine of transubstantiation, according to which, at the consecration, the substance of the bread and of the wine are transformed into the substance of the Body and Blood of Christ, respectively. Alternatively, Christ could be really present in the Eucharist in virtue of some relation he has with the fundamentally located consecrated bread and wine. In contrast to the doctrine of transubstantiation, such derivative location accounts of Christ's real presence in the Eucharist have received scant attention in the recent philosophical literature on the Eucharist. We aim to redress the balance and propose a receptionist account of Christ's real presence in the Eucharist on which Christ is really present to a believer who receives the consecrated bread and wine; the Eucharist is then a mode of, and an occasion for, a second-person experience of Christ. $^{2}$

\section{Fundamental location accounts of the real presence of Christ in the Eucharist}

\footnotetext{
${ }^{2}$ A brief word about terminology would be helpful here. We're using 'mode' as roughly synonymous with 'way'. So, a mode of experiencing a person is a particular way of experiencing them, say, in person, over Skype, by email and so on. An occasion for experiencing a person is a particular time when you experienced that person, say, going to the theatre together last Thursday evening.
} 
If a fundamental location account is correct, then Christ is located at the place occupied by the consecrated bread and wine. But how could Christ be so located, given that the consecrated bread and wine have all of the apparent properties of bread and wine and none of the apparent properties of Christ? Furthermore, how could Christ be multiply located given that Christ is fundamentally located at both of the places occupied by the spatially separated, consecrated bread and wine?

Recently, Alexander Pruss (2013) and Martin Pickup (2014) have addressed these objections, Pruss the former, Pickup the latter, in terms of Christ being wholly present in the consecrated bread and wine, and have argued that these objections can be rebutted successfully. If they are right in each case, then an account of the Eucharist in terms of fundamental location is possible. We argue that their suggestions face serious objections, and that therefore, an alternative is well motivated.

Pruss defines 'being wholly present' as follows:

(WP): $x$ is wholly present in $L$ at internal time $t$ if and only if $x$ exists at $t$ and every intrinsic feature that $x$ has at $t$ is present in $L$ at $t$.

and states the problem it gives rise to for the metaphysics of the Eucharist as follows:

The Catholic view is that Christ's body and blood is wholly present in the location of the Eucharistic species. But by [(WP)] this implies that every intrinsic feature of Christ's body and blood is present there as well. However, Christ has a certain height and a certain mass. Thus, it seems, a certain height is present in the host and certain mass. Now, the height of Christ is several feet and his mass is over a hundred pounds. But how could several feet of height be found in such a small place? And we certainly do not observe such a great mass in the host. (Pruss 2013, 70)

Pruss's suggestion, for which he refers us to his previous work (Pruss 2009), is that features like height and weight are not, in fact, intrinsic properties. He gives two reasons for thinking so. The first, he tells us, is that '[we] learn from Einstein that shape and size depend on a reference frame' (Pruss 2009, 530). Now we do indeed learn from Einstein that shape and size depend on a reference frame, but the conclusion to draw from that is far from obvious. In fact, it is a matter of considerable debate in the philosophy of physics whether it follows that there is, in fact, no fact of the matter concerning size and shape. The debate need not concern us here, however, for as a matter of fact Pruss is simply mistaken. Einstein teaches us that at very high speeds a rectangle will appear square; but no matter how fast the rectangle moves, it will never appear to be a loaf of bread. The same is true of Christ's body: Einstein gave us no reason to think that Christ's human body could have the extrinsic shape of a communion wafer. 
The second reason Pruss gives is that '[we] might also say that the shape and size of an object supervenes on the positions of its parts' (Pruss 2009, 530). Pruss doesn't elaborate, so it isn't clear what to make of this claim. Intrinsic properties, as David Lewis defines them, are properties 'which things have in virtue of the way they themselves are' $(1986,61)$. To deny that something's shape is an intrinsic property because shape 'supervenes on the position of its parts' isn't so much a qualification of the distinction, but a denial of it. Pruss is right that things have the shape they do in virtue of the positions of their parts, but that does nothing to show that shape is, therefore, not intrinsic. Theodore Sider's words are apposite:

...'intrinsic' is partially a term of art. Everyday use and the notion's intended theoretical application provide some non-negotiable constraints on how any notion deserving the name must behave. On any construal of intrinsicality, shape properties like being a perfect sphere should turn out intrinsic; on any construal properties like being within 10 feet of a perfect sphere should not turn out intrinsic. (1996, 10)

If our argument is successful, and Pruss's original problem still stands, the obvious moral to draw from the discussion is to deny that which is forcing the problem, namely (WP): demanding that all of Christ's intrinsic features be present in the Eucharistic species is a mistake. Now at the beginning of his paper, Pruss writes, '[the] basic relation that I will work with is being present in a location' - and indeed, that is the problem. Pruss is insisting on fundamental location, whereas, in fact, derivative location is in order. However, even if our argument is unsuccessful, Pruss has only shown that an account of the Eucharist in terms of fundamental location can escape one of the major objections to it.

Pickup (2014) attempts another solution. He provides an account of how, for two different spatially-located entities A (the bread) and B (the wine), it can be the case that:

RP1: A and B are each the whole body and blood of Christ.

According to Pickup's account, RP1 can be understood by analogy with a case of time travel if we grant the logical possibility of someone hopping into a time machine and reappearing at an earlier time alongside an earlier incarnation of themselves. Presumably they can do this any number of times, and so it is possible for one and the same person, henceforth call her 'Jane', to be instantiated at some particular (external) time $n$ times over, for any $n$. RP1 can be understood analogously to such a case, where A and B correspond to two different instances of Jane. If the time travel case is possible, argues Pickup, then so is RP1.

Apart from depending on the possibility of time travel, which is controversial, we have some additional concerns with this picture. To understand these, we must 
first distinguish between two different possible interpretations of time travel, between which Pickup hopes to remain neutral, namely, endurantism and perdurantism. The difference between endurantism and perdurantism, for the sake of this paper, will simply be that the latter accepts the existence of temporal parts, while the former rejects them. Examples involving time travel will have to be treated very differently by endurantists and perdurantists. We first consider the endurantist version.

If endurantism is true, there are no temporal parts. The different instances of Jane in the time travel case, then, are not temporal parts of Jane. When not being careful with our words, we may describe the room as being filled with $n$ number of Janes. However, this isn't quite right on the endurantist's view, because 'Jane' refers to the single enduring woman. There aren't different Janes, but one. This threatens to become very awkward for Pickup's account of the Eucharist, for we might similarly wonder what ' $A$ ' and ' $B$ ' refer to, if not to temporal parts of the enduring body and blood of Christ. An endurantist might propose that A and B are events in the life of the body and blood of Christ (this seems to be Brian Leftow's $(2004,308)$ view of the Jane case). But that can't be right. Events cannot be broken, eaten or drunk, but the bread and wine can (this point is made by Hasker $(2009,163)$ against Leftow's view). More to the point, events cannot be bodies or blood, at least, not in anything like the ordinary sense of those terms. An endurantist might alternatively say that A and B are spatial, but not temporal parts of the body and blood of Christ. However, this won't vindicate RP1, as A and B would not then each be wholly the body and blood of Christ. The only endurantist alternative that I can think of is to hold that 'A' and ' $\mathrm{B}$ ' do simply refer to the body and blood of Christ itself, and not parts or events of that body and blood. This would entail that $A=B$, that is, that the consecrated bread is numerically identical with the consecrated wine. But is it plausible to say that the bread and the wine are identical? Christians who believe in the real presence of Christ in the Eucharist often speak of 'the two species of the Eucharist'. It seems difficult to understand how there are two species (namely the bread and the wine) of the Eucharist on an altar unless the bread is non-identical with the wine. Perhaps $A$ and $B$ are the same enduring object but falling under different phase sortals ('bread' and 'wine', if these are in fact sortals), but it isn't entirely clear how an endurance theorist can make sense of A and B falling under different phase sortals in a way which doesn't first involve distinguishing between $A$ and $B$, and this raises the problem all over again.

We grant that the situation is better on the perdurantism version of the analogy. If perdurantism is true, according to Pickup, we can conceive of the body and blood of Christ as a perduring object, while conceiving of A and B as temporal parts of this object. According to the perdurantist view, A and B would not be absolutely identical with each other or with the body and blood of Christ. A and B would both satisfy (WP), Pruss's definition of whole presence. However, opponents of multilocation might point out that the perdurantist account of the time travel case may simply suggest that (WP) is too weak a definition of whole presence. If there was some 
external time $t$ at which A and B both existed, at locations $\mathrm{L}_{1}$ and $\mathrm{L}_{2}$ respectively, as temporal parts of some perduring object, then where is the perduring object located? Surely at both. But if this is true, then, it might be objected, A and B must also be spatial as well as temporal parts of the perduring objects. This, it might be thought, is sufficient on its own to show that the body and blood of Christ isn't wholly located in either A or B.

We grant that this is by no means a knock-down objection, and it isn't intended as such. Pickup may well have the resources to respond to the worries that we think confront his proposal. However, the reliance of this account on both the logical possibility of time travel and multi-location, both of which face well known objections, is inescapable and is perhaps the most serious cause for concern. We conclude that the fundamental-location accounts of the Eucharist in the contemporary literature face several serious worries, and we think this provides a good motivation for developing an alternative in terms of derivative location.

\section{A derivative location account: receptionism}

Having argued that neither Pruss nor Pickup successfully rebut objections to a fundamental location account of Christ's real presence in the Eucharist, we propose a derivative location account, one on which the consecrated bread and wine can occasion a particular kind of experience of Christ, namely, a second-person experience of Christ, that is, the consecrated bread and wine are a mode of, and an occasion for, a communicant to experience Christ as a person. In essence, the consecrated bread and wine are icons by means of which communicant and Christ share attention with each other. Let us remind ourselves of what it is for an object $x$ to be derivatively located at a place $p$ :

Derivative Location: $x$ is located at $p$ derivatively $=_{\mathrm{df}} x$ is located at $p$ in virtue of standing in some relation(s), R(s), to some distinct entity, $y$, where $y$ is located at $p$ fundamentally.

On the view we favour, Christ $(x)$ is derivatively located at the place occupied by the consecrated bread and wine $(p)$ in virtue of standing in an 'iconic' relation $(R)$ to the consecrated bread and wine which is located at $p$ fundamentally, where $x$ stands in an iconic relation to $y$ just in case $y$ is a mode of, and an occasion for, a second-person experience of $x$. More simply, the consecrated bread and wine are a mode of, and an occasion for, a second-person experience of Christ. To unpack this view, we first explain the concept of a second-person experience by employing Stump's (2010) analysis of this concept. We then discuss how spiritual practices can occasion secondperson experiences of God by discussing Adam Green and Keith A. Quan's (2012) account of experiencing God through Scripture. We conclude by applying this account to our understanding of Christ's derivative location in the Eucharistic elements. 
In Stump's account of God's omnipresence, she notes that as well as being able to describe a person's presence in relation to a space and a time in terms of present in and present at, we can also add a kind of second-personal presence, namely, present to. This kind of presence is lacking when someone is present in a space and at a time but isn't present to the other persons in the room. For instance, to use Stump's example, we might say that 'She read the paper all through dinner and was never present to any of the rest of us' $(2013,64)$. What is lacking here isn't the agent's presence in a space or at a time, but rather, it is a kind of 'second-personal psychological connection' with the other persons in the room. Stump defines this account of second-personal experience in more detail in Wandering in Darkness. As she describes it here, Paula has a second-person experience of Jerome only if

1. Paula is aware of Jerome as a person.

2. Paula's personal interaction with Jerome is of a direct and immediate sort.

3. Jerome is conscious. $(2010,75-76)$

What is it to interact personally with another person in a direct and immediate sort? And what is lacking from Paula's failing to share attention with Jerome by reading the paper all through dinner? Part of Stump's answer to these questions is that in order to have second-person experience, persons must share attention with one another. Shared-attention, put briefly, is a kind of mutual awareness between persons, this is the kind of experience infants and caregivers have through engaging in mutual eye contact with one another, for example. ${ }^{3}$ Stump argues that we can understand omnipresence in these terms: '[i]n one and the same eternal present, omnipresent God is available to share attention with any person at any place in any time' (2013, 71).

Although we are not interested here in defending Stump's derivative account of omnipresence, we think that it provides a helpful way of thinking about Christ's presence at the Eucharist. On this iconic understanding of Christ's presence, it's not Christ's presence in a place or at a time which is important, but rather, Christ's presence to the individual through a kind of attention sharing. As Martin Luther writes in his discussion of Christ's presence at the Eucharist, 'it is one thing if God is present, and another if he is present for you' (1961). ${ }^{4}$ This presence to an individual is the kind of presence we think that it is important to explain. How can we adopt Stump's account of attention sharing to our understanding Christ's presence in the

3 There is a great deal of secondary literature on the philosophy and psychology of joint-attention (or shared-attention) between persons. See for instance Naomi Elian, Christoph Hoerl, Teresa

McCormack and Johannes Roessler (eds), 2005 as well as Axel Seemann (ed) 2012. Since our account doesn't depend on the psychology of joint-attention to be correct, we avoid going into too much detail here.

4 For another, similar account of Christ's presence to the individual at the Eucharist, see Kierkegaard 2011. 
Eucharist? And how can bread or wafers and a sip of wine allow us to experience Christ in this way?

To see how the Eucharist can provide us with a mode of, and an occasion for, sharing attention with Christ, consider another application of the second-personal model of religious experience, namely, Green and Quan's (2012) account of experiencing God through Scripture. ${ }^{5}$ According to Green and Quan, one way of understanding the claim that God is present in, and speaking through Scripture is to maintain that Scripture gives us a mode of, and an occasion for, a shared attention experience with God. First, it will be important to give a more detailed account of shared-attention. As Green and Quan outline it, 'shared attention occurs when one is engaged in an act of attending to something and, in doing so, one is cooperating with another who is engaged in a parallel act of attending. Shared attention involves coordinated "attention-focusing"' (2012, 419). This kind of shared attention can either be dyadic, in which case two individuals focus attention only on one another, or triadic, in which case both attendants focus on an independent object or event. Further, it is important that shared-attention is coordinated attention rather than merely 'mutual object focusing' (Brinck 2001, 262). When a mother and child share eye contact they enjoy dyadic shared-attention. If the child points to a bright light in the room and the mother follows her gaze there is mutual object focusing. When the child looks back to see that her mother has followed her gaze, there is triadic shared attention. Cooperation is a crucial component of shared attention and thus if the mother leaves the room whilst the child looks over to the bright light, the experience will be a very different one. According to Green and Quan 'the cooperation of the other in attending is a phenomenal constituent of the experience of shared attention itself' $(2012,420)$.

With this model in place, Green and Quan discuss more specifically how written text may allow one to share attention. They consider the following two cases:

Case 1

Becky likes to cook along with the Rachael Ray show. The show is on the Spanish-speaking channel during her dinner hour, and Becky does not speak Spanish, so she follows the English subtitles. When Ray says "Consider the golden brown crust of this zucchini bake" Becky is able to use her abilities to engage in shared attention as mediated by the subtitles to attend to the zucchini bake pictured on the screen. She then imagines what Rachael Ray would say about the zucchini bake that Becky is cooking and is led to look at the crust of her own zucchini bake, pondering whether it is golden brown as it should be.

Case 2

\footnotetext{
${ }^{5}$ For another account of second-personal experience, but applied to religious art, see David Efird and Daniel Gustafsson 2015.
} 
Alex wins a private cooking lesson with Rachael Ray. He is deaf, so Rachael communicates with him using written notes. At a certain point in the lesson, she hands him a note that reads, "Consider the golden brown crust of this zucchini bake," at which point he attends with Rachael to the crust. He looks back at Rachael who smiles and holds out a note between them that reads, "You done good." $(2012,423)$

In Case 1, Becky doesn't share attention with Rachael Ray, since Ray isn't present for her to share attention with. However, she uses the same abilities that she uses when genuinely sharing attention with another person. Becky's reading of the subtitles allows her to focus on the object of attention which Rachel Ray wishes her audience to focus on and also to 'navigate her own environment in light of what she reads' $(2012,423)$. According to Green and Quan, Case 2 is an example of genuine shared attention; the first note which Alex reads functions much like a child's point towards the light and is an example of triadic shared attention mediated by text. The second note is an example of dyadic shared attention in which Alex and Rachel share attention with one another.

These examples serve as the basis for the distinction which Green and Quan make between 'genuine' and 'pseudo' shared-attention. Pseudo-shared-attention isn't an illusion of shared attention, but rather, a kind of 'as if' attention sharing whereby the individual 'processes an input in an "as if" mode (e.g., "as if" the person on the TV were present' $(2012,423)$. Genuine shared attention through text occurs when two individuals cooperate in attention sharing in either the dyadic or triadic variety. They extend this taxonomy of genuine shared attention further by dividing this experience into an 'instrumental' and 'constitutive' shared attention. They give the following example to demonstrate this difference:

if Rachael Ray hands Alex a note that says, "My producer Buddy is in the next room and he wants to give you a new blender," Alex may then be empowered by the note to have dyadic and triadic shared experiences with Buddy, but the note is not part of any cooperative activity shared by Alex and Buddy. The note is only a means of putting Alex in a position to engage in shared attention with Buddy. $(2012,422)$

An instrumental shared-attention experience is different from a pseudo-sharedattention experience in that it alerts Alex to an actual agent (Buddy) who is available to share attention with him.

With these distinctions outlined, Green and Quan consider the theological claim that God speaks through or is present in the text found in Scripture. According to Green and Quan, if text can allow us to share attention in various degrees with other persons, then the same can be true of God. For instance, one might have a kind of pseudo-shared-attention experience with God when one reads the story of the healing of the paralysed man in the Gospel according to Mark, chapter 2; we might 
imagine ourselves in the position of the man and read the words 'Son, your sins are forgiven' as if they are being spoken directly to us. However, according to Green and Quan, pseudo-shared-experience cannot account fully for God's continuing presence and speaking through Scripture. Pseudo-shared-attention is possible with other literary texts, such as Plato's account of Socrates in the Republic, for example. However, ' $[t]$ he Christian tradition appears to assert that Scripture is unique in that God is actually present and speaking in Scripture, not just that Scripture lends itself toward imagining that God is present and speaking' (2012, 425). Thus, Green and Quan claim that Scripture can also act as an instrumental shared-attention experience, alerting one to the presence of an agent (God) who is able to shareattention with you, much like the previous example of passing a note. For example, "[w] hen the psalmist writes, "Taste and see that the Lord is good," it represents the world as being a place that includes a divine being whose goodness is available for the experiencing' $(2012,425)$. It is even possible, Green and Quan argue, to have a constitutive shared-attention experience with God:

Much like Rachael Ray hands Alex a note about the zucchini bake to direct his attention to the zucchini bake in Case 2, so God might, through the Scriptures, direct one's attention to one's pride. Just as Ray hands Alex a note saying he "done good" that shapes how Alex experiences Ray's kindly smile, so God might elect for the contents of Scripture to shape a dyadic experience of the divine. Shared attention requires that the agent one is sharing attention with be experienced as present, even if implicitly. Thus, the constitutive reading draws a tight link between the role that the text plays in facilitating shared attention and God's being present. $(2012,426)$

Green and Quan note that whilst 'as if' experiences might be the most common, it is possible for these experiences to act as a prime for us to experience scripture in an instrumental and constitutive way. Pseudo, or 'as if', shared-attention experiences encourage us to engage with Scripture and to enter into the 'cooperative activity with the divine in which God uses the text of the Scriptures to reveal Himself dyadically or triadically'. Thus, the model of experiencing God through Scripture which Green and Quan present, allows for a kind of progressive experience of God-starting with the facilitation of an imaginary, or 'as if' experience, and working towards genuine constitutive shared attention. The advantage of this is that the model isn't an all or nothing approach; whilst it is true that God is only really present when he is present to the individual constitutively, the other modes of attention-sharing may facilitate this kind of experience in the future.

Now, whilst it might be clear how two persons can share-attention through sharing eye contact, for instance, it might be more difficult to grasp how a person could attend to the mind of God in the same way. We cannot share eye contact with God or perceive God's body language in the same way that Alex interacts with Rachel 
Ray. All of the above examples of sharing-attention involve persons who are fundamentally located nearby to one another. However, we have claimed that Christ cannot be fundamentally located in the Eucharistic meal.

Whilst many of the examples given by Green and Quan are cases in which persons can direct perceive one another, nearness of fundamental location is not necessary for the model of shared-attention they employ. As Green explains this model elsewhere,

the pattern of one's experience appears to manifest a shared awareness between the divine and oneself within which affect and information can be communicated. [...] [U]sing the shared-attention account, we can claim that sound, light, and affect are all mediums that can be manipulated by God in such a way as to reveal the mind of God toward the subject of the experience. The subject hears the sound of a voice reading a psalm that responds to his situation, a manipulation of auditory stimulation that evidences an awareness and concern for the subject by some theistically affiliated entity. He or she then experiences an unnatural light which seems patterned to reinforce the extra-natural nature of the reassuring voice. Then, the subject has the experience as of being loved and then one of peace, perhaps through the activation of the subject's mirror neurons or perhaps in another way. The preceding pattern of light and audition does not seem epistemically incidental to the experience of being loved. The shared-attention model allows the preceding pattern of sensory imagery to enter into how one experiences whatever qualia were present in the experience such that it is experienced as being loved by God. (2002, 463-464)

The shared-attention model of religious experience depends on a person's ordinary perception of the world, but unlike all of the above examples of shared-attention between human persons, in the case of divine-human shared attention what is perceived is not the body of God. As Green describes it, a person becomes aware of God's personal presence in a mystical way, but through her ordinary experiences of the word.

If Green's model is a feasible explanation of experiences of divine presence and if text can allow us to share-attention with another person (including a divine disembodied person), then so too can an object or an event, we think. Green's model of mystical experience can be extended beyond sharing-attention through text. Objects often portray meaning in a rich and evocative way, and allow for intersubjective experience. Consider a further example of attention-sharing:

Case 3

Alex and Rachael have been married for 50 years. On their first date, Alex cooked Rachael a steak with peppercorn sauce and green beans. 
Recently, they have been having difficulties in their marriage, but decide to devote the evening to spend together. Alex comes in the room and looks at Rachael, and presents her with a plate of steak with peppercorn sauce and green beans. Rachael looks back at Alex, without saying anything and smiles at him, whilst placing her hand over her ring finger.

Now, just as in the Rachael Ray cases, in this case, nothing is spoken and an observer might miss the significance of this interaction. However, in the presentation of certain actions and the repetition of past acts, Alex is able to share-attention with Rachael in a way which far surpasses what he could have written in a card or said in words. The mutual focus on an object allows for Alex and Rachael to share-attention both dyadically (mutual awareness) and triadically (mutual object awareness), furthermore it is an experience which allows Alex to communicate something important to Rachael without using text or speech. Clearly, if text can allow for meaningful shared-attention between persons, then so too can objects and events.

The application to the Eucharist should seem obvious by now. We have shown that according to Green and Quan, the reading of a piece of text can allow for mystical attention-sharing with God. We have also shown that an analogue of this experience can be had through the experience of a significant event. Thus, it follows that some kind of event could also allow for an experience of a divine person who is not fundamentally located nearby to the perceiver. Now let's see how this can be applied to our understanding of the Eucharist.

For the Christian believer, the Eucharistic meal has a significance much like the significance of Alex's reconciliation meal with his wife. The Eucharist is a reconciliation meal-it's content is focused on Christ's sacrifice on the cross, the forgiveness of the participant's sins and the possibility of closer union with Christ. This will sometimes be formalised by means of liturgy which focuses the participant's attention onto these components of the sacrament, but as with Alex and Rachael's reconciliation meal, clearly propositional content isn't necessary for this kind of attention sharing. Through the Eucharistic elements, the participant is able to focus her attention on Christ in a way which is very similar, albeit in some ways different, to that of the way text can occasion attention sharing between persons. Notably, however, as with Alex and Rachael's meal, what is communicated isn't a set of propositions, but the sacrament will have a different meaning depending on the participant's relation to Christ.

Green and Quan's model of attention-sharing through text gives us a helpful dichotomy to outline the kinds of experience that the Eucharist might allow for. As with their discussion of experiencing God through Scripture, these experiences can function progressively, starting with pseudo shared-attention experiences, and then eventually allowing the individual to have a constitutive shared-attention experience through participating in the Eucharist. We'll outline these different levels of experience, but it's important to note (as with Scripture) that in order to make sense 
of the claim that Christ is present in the Eucharist, only a constitutive sharedattention experience will do. So whilst pseudo and instrumental experiences might enable an individual to eventually experience Christ constitutively, they won't count as examples of Christ being present in the Eucharist by being present to the participant.

First, then, it is obvious that participation in the Eucharist can occasion an 'as if or pseudo shared-attention experience, whereby the participant focuses on the death of Christ and the forgiveness of sins when she partakes in the sacrament. When she hears the words 'Take, eat; this is my body which is broken for you: this do in remembrance of me' (1 Corinthians 11.24), she receives the bread and wine as if it is given to her from Christ at the Last Supper. Secondly, the Eucharist can also be thought of instrumentally. In this regard the participant eats the bread and drinks the wine and this reminds her that Christ died for her, and what's more, that his presence is active today, that is, that he is a living agent with whom we can share attention with. The words of the Anglican liturgy seek to remind the individual of God's presence; in response to the priest's words: 'The Lord is Here', the congregation reply 'His Spirit is With Us' (Common Worship 2000, 176). ${ }^{6}$ These two kinds of experience seem uncontentious, but not sufficient for the account of derivative presence we have defended.

For the model we propose, it is important not only that the participant is reminded that Christ is present, but also that she actually experiences him as being present. Much like Alex and Rachael share attention which is focused on a reconciliation meal, Alex and Christ must share attention by focusing on the Eucharistic meal, which is able to bring about reconciliation between them. Clearly, unlike with Rachael, Alex cannot share-attention with Christ by means of eye contact, since Christ isn't visibly present. Nevertheless, Alex can still be aware of Christ's presence to him. The advantage of a shared-attention model of religious experience is that we don't have to postulate any kind of mystical sensory apparatus. But rather, we can have an experience of someone as present to us through a number of different media. ${ }^{7}$ Stump $(2010,77)$ claims that even an email exchange can allow for secondpersonal experience. For Alex's participation in the Eucharist to count as an experience of Christ as present to him, he must be aware that Christ is present and that Christ is attending to him. As Søren Kierkegaard puts it, '[i]n the physical sense, one can point to the Communion table and say, "there it is"; but in the spiritual sense, it is actually there only if you hear his voice there' (2011, 271). In partaking in the bread and wine, Alex can be aware that Christ is aware of him and he can be reminded of the act of grace which Christ performed on the cross, or of some unconfessed sin in his heart through the powerful repetition of Christ's last meal. He is aware that Christ

\footnotetext{
${ }^{6}$ The role of the Trinity in the experience of Christ in the Eucharist is an issue which we don't have space to address in this paper. As we describe it, the Father makes the Son present to the individual by the power of the Holy Spirit. Thus, the congregation's use of 'His' in the reply that 'His Spirit is With Us' should be interpreted specifically as referring to Christ.

${ }^{7}$ See Adam Green 2009, 455-457 for a defence of this claim.
} 
too is present and focusing on this meal and the things that stand in the way of their reconciliation. The elements occasion both a dyadic and triadic shared attention of Christ and Christ is derivatively present in the Eucharistic elements.

Whilst the Eucharist always has the potential to occasion this kind of constitutive shared-attention with Christ, it might not always be successful in producing the rich kind of experience described by a genuine dyadic or triadic sharedattention. Communicants may enter into, and experience this union-the richness of the relationship, to varying degrees. This may be because of their maturity in understanding their relationship with Christ, and their own need for God. But it may also be due to inattention to some or all aspects of how Christ is presenting himself to them-the communicant may just not be receptive at that time. It may be that the factors that are inhibiting the person's awareness and receptivity may be due to the service being conducted in an unfamiliar tradition, or in a community to which the person doesn't yet belong. Thus, although a person may participate in a church service, this doesn't mean that they have necessarily experienced a certain degree of, or indeed any, union with the present person of Christ. As Green and Quan (2012) have demonstrated, how much experience, or awareness, of the presence of Christ there is can vary. But wherever some real union has taken place that encompasses to some minimal degree the essential aspects of the meal Jesus was instituting (the experiences of the need for redemption, of God as the provider of redemption, of participation in the security of covenantal relationship, and of eschatological hope) then Christ has been truly present and the Eucharist has been truly celebrated. ${ }^{8}$

In the concluding sections of this paper, we address two important issues which face an iconic model of Christ's presence in the Eucharist. First, we respond to the question of what makes the Eucharist distinct from other instances of experiencing Christ's presence. And second, we ask whether our model can actually explain the doctrine of Christ's presence in the Eucharist, and if it can, we ask, where precisely is Christ supposed to be located?

\section{What makes the Eucharist special?}

One advantage of focussing on the actual interpersonal interactions experienced is that we are able to connect the experience and benefits of participation in the Eucharistic meal with the interactions and benefits occurring in the rest of Christian spirituality, both within a sacramental framework, and beyond. ${ }^{9}$ The nature of the

\footnotetext{
${ }^{8}$ We don't have time to discuss a further corollary of this claim, but it is worth noting: there is nothing in what we have said that would prohibit this meal being celebrated with a bottle of Coke and a bag of crisps. Although people in many (probably most) traditions would find this practice so unusual and unsettling as to disrupt their ability to relate the elements to the meaning they would usually confer on bread and wine, it is in principle possible for Christ to be truly present within such a practice.

9 The importance of this is emphasised by Charles Davis:
} 
interaction between the individual and Christ isn't different in kind from the nature of interaction which it is possible to have in prayer, worship, holy contemplation or any other activity that admits of the possibility of experiencing an intimate encounter with Christ. Thus, the Eucharist isn't different in kind from any other form of sacramental (or otherwise) union. This invites the question: What makes the Eucharist special? ${ }^{10}$ That is, if Christ's presence in the Eucharist is understood derivatively as a mode of, and an occasion for, second-person experience of Christ, and the Christian can enjoy shared-attention and second-person experience of Christ through the reading of Scripture, prayer and experiencing Christian art (to name but a few examples), then there is nothing unique or distinctive about the Eucharistic sacrament.

To answer this question, of what makes the Eucharist special, it will be important to note that although the interaction between Christ and the individual isn't different in kind from other interactions with Christ, it is different in degree and content, and understanding this difference is important for understanding the role of the elements in the interaction that occurs.

While the clear focus on Christ's work on the cross provides a special opportunity to be sensitive to experiencing Christ in the aspects we have already discussed, it doesn't seem in principle, that the same content of experience of, for instance, God-as-provider-of-redemption could not also be gained through earnest prayer where the content of the conversation the Christian is undertaking with God in prayer is aimed at their growing to understand and appreciate this aspect of their relationship with Christ. However, the Eucharist is special, and unique in the sense that it is a corporate opportunity of focus on Christ in a distinct way, and one that is at the centre of Christian being. It does stand out as an opportunity to focus on the work of Christ on the cross more than in any other regular tradition of the church. But although special in this way, the content of the experience, and the possible scope of interaction found in the Eucharist, isn't necessarily unique to participation in it. If we were to imagine a person who for some pathological reason found it impossible to engage in the Eucharist in a church service, we can still imagine them to have both the personal and corporate aspects of experiencing Christ in the relevant ways through participation in a prayer retreat with a group. Space doesn't permit us to give

Catholic piety has projected upon the sacramental presence the role in the Christian life that properly belongs to the presence of Christ by grace [...] the inward and permanent presence by grace, to which the Eucharist itself is directed, has been forgotten. [...] The Eucharist is the expression and cause of our personal union with Christ, which is a permanent and mutual personal presence. It is a personal encounter with Christ in which he once again offers us union with himself, and invites us closer, and in which we accept and draw nearer to him. $(1968,159)$

10 Or, as Martin Luther puts this problem, 'If Christ's body is everywhere, ah, then I shall eat and drink him in all the taverns, from all kinds of bowls, glasses, and tankards! Then, there is no difference between my table and the Lord's table' $(1961,67)$. 
examples for each and every aspect of the Eucharist we have discussed, but there is no reason in principle to think that matters will be different for other aspects, though experiencing Christ in some way may well be more straightforward in the Eucharist than elsewhere. ${ }^{11}$ So Christ commands the disciples to continue with the practice he institutes because it is good for them, and beneficial. ${ }^{12}$ But not because it is necessary, and without it there would be some aspect of union with Christ that they would be unable to enter into.

By participating in the Eucharist we experience the real presence of Christ, and this interaction is the metaphysical core of what makes it the transformative and spiritually nourishing activity that it is. But if this interaction is in principle possible without the elements, how do the elements have a special role to play when it comes to the presence of Christ being available to us? If their role is more than mnemonic, but doesn't extend as far as being substantially the body and blood of Christ, as we have already discussed, then what else is there. Well, like much human activity involving interaction there is an element of communication-of expression-to the Eucharist. Forms of liturgy, and more informal verbal articulations in the Eucharist, vary widely. But the core central element to the tradition are the receiving of bread and wine along with an acknowledgement of their representative function as the body of Christ and the blood of the new covenant respectively. The elements have a powerful symbolic function that goes beyond corporate storytelling or provoking reflection. In receiving the elements we accept Christ's offer of himself through a tangible physical expression. This goes beyond our acknowledging that we have in the past accepted Christ as saviour, and is a present act of reception that we communicate to God, in the presence of, and with, our spiritual community, through

\footnotetext{
${ }^{11}$ Note that if we had argued that the Eucharist was the actual offering of a new sacrifice, then this would be an aspect that it would be difficult to imagine replicable in prayer.

12 Especially given that this meal provokes the participant to experience Christ in a complete set of aspects, which make up an important focal point in our regular Christian life and experience. Luther makes a similar response to this question, noting that
}

although he [Christ] is everywhere, he does not permit himself to be so caught and grasped; he can easily shell himself, so that you get the shell but not the kernel. Why? Because it is one thing if God is present, and another if he is present for you...since Christ's humanity is at the right hand of God, and also is in all and above all things according to the nature of the divine right hand, you will not eat or drink him like the cabbage and soup on your table, unless he wills it. He also now exceeds any grasp, and you will not catch him by groping about even though he is in your bread, unless he binds himself to you and summons you to a particular table by his Words, and he himself gives meaning to the bread for you, by his Word, bidding you to eat him. This he does in the Supper, saying 'This is my body', as if to say 'At home you may eat bread also, where I am indeed sufficiently near at hand too; but this is the true toutou, the 'This is my body': when you eat this, you eat my body, and nowhere else. Why? Because I wish to attach myself here with my Word, in order that you may not have to buzz about, trying to seek me in all the places where I am; this would be too much for you, and you would also be too puny to apprehend me in these places without the help of my Word. $(1961,69)$ 
receiving the bread and wine. Receiving Christ, and entering into closer union with his presence is an action, is something we do-an action. It is an action involving our relational dispositions, intentions and affections. Like all interpersonal actions, they involve both parties, and become real through their manifestation. Without participation of both persons, they remain a subjective imagining within. Love, companionship, comforting, encouragement, and so on are relational because they find a cooperative manifestation that not only communicates the content of the relational interaction, but also is that interaction. So also in experiencing the offer and reception of Christ, the receiving of the elements not only communicates our reception of Christ and his work, but because of the representative meaning vested in the elements by Jesus at the Last Supper, it is the act we perform by means of which we instantiate that reception in a relational action.

\section{Locating the real presence of Christ in the Eucharist}

Recognising this will assist us in thinking about where we place the presence of Christ. It isn't strictly true to say that the presence of Christ is located in the elements-at least this isn't true at face value as matters are not that straightforward. The presence of Christ is located in the interaction between Christ and the communicant-the real presence of Christ is manifested and experienced in this interpersonal union. However, for the communicant, this relational interaction is manifested by taking the elements. So, it isn't a mere gloss to claim that Christ is present in the elements, as long as this isn't taken to be the claim that Christ is present substantially because the bread and wine are the substances Christ's body and blood. This is just not the aspect of Christ's real presence that we are interested in. ${ }^{13}$ The substantial presence of Christ was no guarantee of any interpersonal union, or meaningful interaction, for those in the first century, and neither is it for us today.

The presence of Christ we are interested in involves relationship. The aspect of the elements' function that is the vehicle for this relational interaction is the aspect under which it is then true to say that Christ is present in the elements. Christ isn't present substantially, but derivatively, because he is really present to us in relational union through our partaking of the elements. Notice that strictly Christ is present (to us) in our taking of the elements. If the elements were to lay unused after the service, or indeed to be eaten by a church mouse, they would fail to be aptly described as the body and blood of Christ, since they would no longer be involved in any interpersonal interaction. We should also note that the 'real presence of Christ' is shorthand for a more complex manifestation of Christ's real presence that falls under his presenting himself in the ways pertinent to these symbols-his offering his body and blood, and

\footnotetext{
${ }^{13}$ Note that the metaphysical puzzles of multi-location, and of essences and accidents, associated with transubstantiation, just don't arise in this view-in this sense, it is as metaphysically undemanding as the memorialist view. At all times the elements remain substantially bread and wine.
} 
all that that means to us as we interact with this (which we have discussed at length above). So to be more precise, though also more laborious, Christ is 'bodily' present in terms of being present in a way that allows us to interact with the offering of his real body and all that this means to us, and his 'blood' is present in terms of the significance and reality of the union and covenant bound in his blood being actually experienced by us through our taking ourselves to be representatively partaking of his real blood.

As Charles Davis (1968) suggests, in a transignificationist view of the Eucharist, it is correct to say that the elements are the body and blood of Christ because what something is, considered in terms of what role it plays for us as we interact with it, is a matter of how we treat that thing. Thus, the referring terms we use to denote objects are correctly applied by analysing whether those objects function in a way that meets the criteria of those terms considered as a human category of thought by which we delineate the type of things objects are. However, there are many ways in which it may be true to say that the elements 'are' the body and blood of Christ in this sense-because of the way in which we treat them, without it being true that they are the vehicle, or manifestation, of the sort of interpersonal interaction we have delineated. The concern here is that it may be subjectively true that we treat the elements in a certain way, that makes the use of some terminology appropriate under our own usage, but that there should be some further objective basis for the truth of the state of affairs obtaining - Christ is really present, that doesn't depend on our usage of terminology or on human categories of thought. The transignification view doesn't go far enough in telling us what sort of treatment of the objects is at work in making it true that they are, to us, the body and blood of Christ. ${ }^{14}$ Once we do go further and spell out how we are treating the elements, and the role that they are playing in the experience of, and interaction with the person of Christ, we end up with the view we have outlined above. But by now, we do not need to claim that it is true that the elements are the body and blood of Christ in Davis' transignificationist sense. We arrive at an objective basis for the question of whether Christ is really present that depends solely on whether the state of affairs - Christ's being present (in the discussed sense), actually obtains.

It will be informative to quickly consider how this view compares to two test questions proposed by Michael Dummett (1987) as a test of the acceptability of a theory of presence in the Eucharist. ${ }^{15}$ Dummett suggests that the answer to the question of whether the elements are the body and blood of Christ should be an unqualified 'yes'. Furthermore, the ability to provide this answer should depend on a genuine belief in the incarnation. By unqualified Dummett seems to have in mind ruling out the sorts of qualifications that could be offered by memorialists, whereby we say yes in virtue of Christ being present anyway, and our being provoked to relate to Christ through the symbolic meaning of the elements alone (since Dummett goes

\footnotetext{
${ }^{14}$ Other objections have also been raised, and the view also rests on a questionable view of how terms of reference relate to the nature of objects.

15 This isn't necessarily to endorse Dummett's criteria as necessary, or even sufficient.
} 
on to offer some qualification in exposition of his own view). As the discussion in the last two paragraphs should have made clear, it is correct for us to say that the elements are the body and blood, and that the real presence of Christ is manifest in the Eucharist. But notice that it is also true that without genuine belief in the incarnation it is impossible to truly claim that the Eucharist contains the real presence of Christ. Without belief in the incarnation, it would be impossible to relate to Christ and his work through interaction with his presenting himself to us under the body and blood. If Christ has not become incarnate, then the proffered relationship is just not one that exists except in the imagination. So, without the interaction taking place, it is true to say that there is no real presence, and only the presence of bread and wine. So Dummett's criteria are satisfied, this view affirms that the real presence of Christ is in the Eucharistic meal (as an event) due to the interpersonal interaction that takes place through participation in it.

\section{Conclusion}

Having discussed the different ways in which we can understand the claim that Christ is present in the Eucharist, we have seen that an account of Christ's fundamental location in the elements faces difficulties. In contrast to a fundamental understanding of Christ's presence, we have argued for a derivative account of Christ's being present to the individual in which the elements serve as mode of, and an occasion, for a second-personal, shared-attention experience with Christ. This receptionist view describes the Eucharist as a sacrament in which the participants engage with and interact with Christ as a living person. And thus, as well as avoiding the metaphysical difficulties associated with fundamental accounts, a receptionist account of the Eucharist has a much greater potential for explaining the transformative power of the sacrament in the spiritual life of the participants. As we have seen, this position can still make sense of the claim that Christ is present in the Eucharist, and we are also able to explain the uniqueness of this sacrament, compared with other experiences of Christ's presence. Thus, the position we have developed here is both philosophically robust as well as being able to account for the centrality and importance of this practice in lives of Christian believers.

\section{Bibliography}

Brinck, Ingar. 2001. 'Attention and the Evolution of Intentional Communication.' Pragmatics and Cognition 9: 259-277.

Common Worship: Services and Prayers for the Church of England. 2000. The Archbishops' Council of the Church of England. 
Craig, William Lane and J.P. Moreland. 2003. Philosophical Foundations for a Christian Worldview. InterVarsity Press.

Davis, Charles. 1968. 'Understanding the Real Presence.' In The Word in History: The St Xavier Symposium, edited by T. Patrick Burke. Collins.

Dummett, Michael, 1987. 'The Intelligibility of Eucharistic Doctrine.' In The Rationality of Religious Belief: Essays in Honour of Basil Mitchell, edited by William J. Abraham and Steven W. Holzer. Clarendon Press.

Efird, David and Daniel Gustafsson. 2015. 'Experiencing Christian Art', Religious Studies 51: 431-439.

Elian, Naomi; Christoph Hoerl; Teresa McCormack; and Johannes Roessler (eds). 2005. Joint Attention: Communication and Other Minds: Issues in Philosophy and Psychology. Oxford.

Enright, Anne. 2015. The Green Road. Jonathan Cape.

Green, Adam. 2009. 'Reading the mind of God (without Hebrew lessons): Alston, Shared-Attention and Mystical Experience.' Religious Studies 45: 455-470.

Green, Adam and Keith A. Quan. 2012. 'More Than Inspired Propositions', Faith and Philosophy 29 (2012): 416-430.

Hasker, William. 2009. 'A Leftovian Trinity', Faith and Philosophy, 26: 154-166.

Hudson, Hud. 2009. 'Omnipresence.' In The Oxford Handbook of Philosophical Theology, edited by Thomas P. Flint and Michael Rea. Oxford University Press.

Hoffman, Joshua and Gary S. Rosenkrantz. 2002. The Divine Attributes. Blackwell.

Hudson, Hud. 2014. The Fall and Hypertime. Oxford University Press.

Inman, Ross. Forthcoming. 'Omnipresence and the Location of the Immaterial', Oxford Studies in Philosophy of Religion; available in manuscript http://www.rossdinman.com/Ross_Site/Online_Papers_files/Omnipresence $\% 20$ and $\% 20$ the $\% 20$ Location $\% 20$ of $\% 20$ the $\% 20$ Immaterial $\% 20 \% 282-23$ 15\%29\%20Final\%20Submission\%20.pdf

Kierkegaard, Søren. 2011. Discourses at Communion on Fridays. Translated by Sylvia Walsh. Princeton University Press.

Leftow, Brian, 2004. 'A Latin Trinity.' Faith and Philosophy 21: 304-333. 
Lewis, David. 1986. On the Plurality of Worlds. Blackwell.

Luther, Martin. 1961. 'That These Words of Christ “This Is My Body,” etc., Still Stand Firm Against The Fanatics.' In Luther's Works, Word and Sacrament III, edited by Robert H. Fischer. Fortress Press.

Oakes, Robert. 2006. 'Divine Omnipresence and Maximal Immanence: Supernaturalism versus Pantheism.' American Philosophical Quarterly 43: 171-179.

Pruss, Alexander. 2009. 'The Eucharist: Real Presence and Real Absence', In The Oxford Handbook of Philosophical Theology, edited by Thomas P. Flint and Michael Rea. Oxford University Press.

Pruss, Alexander. 2013. 'Omnipresence, Multilocation, the Real Presence and Time Travel.' Journal of Analytic Theology 1, May 2013.

Seemann, Axel (ed). 2012. Joint Attention: New Developments in Psychology, Philosophy of Mind, and Social Neuroscience. MIT Press.

Sider, Theodore. 1996. 'Intrinsic Properties.' Philosophical Studies 83: 1-27.

Stump, Eleonore. 2010. Wandering in Darkness. Oxford University Press.

Stump, Eleonore. 2010. 'Omnipresence, Indwelling, and the Second Personal.' European Journal for Philosophy of Religion 4: 29-53.

Swinburne, Richard. 1993. The Coherence of Theism. Oxford University Press.

Taliaferro, Charles. 1994. Consciousness and the Mind of God. Cambridge University Press.

Wierenga, Edward. 2010. 'Omnipresence', in A Companion to Philosophy of Religion, edited by Charles Taliaferro, Paul Draper, and Philip L. Quinn. Blackwell. 